\title{
GARCÍA LLERENA, VIVIANA $M$. De la Bioética a la Biojurídica: el principialismo y sus alternativas
} Granada, España, Editorial Comares, 2012, 222 pp.

Este texto es relevante y necesario —imprescindible si se quiere- para quienes desean profundizar en los orígenes y evolución de los principios bioéticos, debido a que existen pocas referencias de calidad escritas en castellano.

¿Por qué resulta tan importante el conocimiento de los principios? La verdad es que, en palabras de la propia autora, "Sin un conocimiento siquiera mínimo del principialismo, sus limitaciones y reformulaciones, así como de los otros modelos elaborados con la intención de reemplazarlo, difícilmente serán posibles la crítica extrasistemática y contextual a las normas positivas, su reinterpretación o modificación."

Efectivamente, como advierte la autora, el principialismo norteamericano ha influenciado y definido el quehacer bioético occidental, sin mayores distinciones locales, como si la fórmula principialista todo lo fuese y todo lo pudiese, convirtiéndose, en palabras de J.F. Drane, "en el paradigma dominante de la bioética". Siguiendo a este autor, "si la bioética refleja el ethos de las civilizaciones del siglo XXI; siendo la medicina y las ciencias de la vida en nuestro período histórico lo que la religión y la salvación fueron a los tiempos medievales", resulta imprescindible cuestionarse si el principialismo clásico, como paradigma dominante, es realmente el método idóneo para cumplir tan enormes expectativas.

$\mathrm{Al}$ inicio del libro, la autora distingue ente reglas morales, teorías morales comprehensivas y el carácter fundamental y normativo-generatriz de los principios. Una vez realizadas estas distinciones, hace una extensa y minuciosa recopilación de autores que se han referido a los principios bioéticos, partiendo por los clásicos de Georgetown, aludiendo a la jerarquización, primacía, propuestas y conflictos elaborados por esta escuela, para llegar finalmente a la proposición europea representada en la "Declaración de Barcelona".

Sobre esta última, reconoce que la visión ética-antropológica, con una fuerte dimensión social y ecológica-medioambiental, es preferible a la autonomista norteamericana, aunque reconoce que el principialismo europeo no logra sustentabilidad como modelo normativo, causando disonancias interpretativas, sobre todo en materias biojurídicas. Así, la dignidad — entendida como principio— resulta insuficiente para ser aplicada a materias de bioética global y ecológica medioambiental.

La autora no agota su estudio en estas dos propuestas fundamentales - el principialismo norteamericano y europeo-, sino que analiza modelos alternativos, como la "bioética casuística", inspirada fuertemente en el casuismo inglés. Prosigue con la "Common Morality", nacida en el seno de la ética biomédica, en la cual los eticistas se avocan a la construcción de sistemas morales que pretenden aplicar posteriormente a la vida real.

En el capítulo IV se refiere a "otras orientaciones bioéticas", que escapan hacia una sistematización metodológica para el juicio moral, constituyéndose, en palabras de la autora, "en la puerta de entrada por la que la subjetividad pueda entrar en el mundo moral”. Otras orientaciones bioéticas mencionadas en la obra son: la ética de la virtud, la ética del cuidado, la ética narrativa y la bioética hermenéutica.

Concluye que la elaboración más inclusiva de la realidad posmoderna — que supone una multiculturalidad y un marcado pluralismo moral - debería estar dada por una cosmovisión venida desde el mundo de los derechos fundamentales en cuanto moralidad común, como una verdadera fuente de 


\section{Recensiones}

autoridad capaz de legitimar lo decidido. Así, desde el mundo del Derecho, la teoría de los derechos humanos resulta ser el mecanismo idóneo para funcionar en una ética global.

Isabel Cornejo Plaza 